\title{
Pemberitaan Sriwijaya Air 182 dalam perspektif jurnalisme optimis dan air mata
}

\author{
Filosa Gita Sukmono', Mohammad Jafar Loilatu², Qholiva Yuni Fadila ${ }^{3}$ \\ 1,2,3 Universitas Muhammadiyah Yogyakarta, Indonesia
}

\begin{abstract}
ABSTRAK
Jatuhnya pesawat Sriwijaya Air 182, jurnalisme optimis, jurnalisme air mata serta perlombaan dalam menyampaikan sebuah berita secara cepat dalam media online menjadi pijakan sekaligus pemantik awal penelitian ini dilakukan. Pintu masuk dari penelitian ini adalah memahami dua konsep penting yaitu jurnalisme optimis dan air mata. Jurnalisme optimis arahnya tidak mengeksploitasi penderitaan korban bencana, mengedepankan sensitivitas pada penderitaan korban bencana, informasi mitigasi bencana diperhatikan dengan baik, fungsi edukasi media menjadi aspek utama, optimisme pada korban menjadi perspektif utama. Sedangkan jurnalisme air mata dekat dengan mengeksploitasi penderitaan korban bencana, tidak memiliki sensitivitas pada penderitaan korban bencana, informasi mitigasi bencana kurang diperhatikan, fungsi edukasi media kurang, mencampurkan mitos dengan berita tidak mengedepankan optimisme pada korban. Tujuan penelitian ini dilakukan untuk menjawab terkait posisi jurnalisme optimis dan jurnalisme air mata dalam pemberitaan media online di Indonesia ketika kasus jatuhnya Sriwijaya Air di awal tahun 2021. Media online yang dipilih dalam penelitian ini adalah detik dan okezone. Menggunakan metode penelitian kualitatif dengan analisis media steps coding conten, dan menggunakan Nvivo sebagai alat analisis. Hasil penelitian ini menunjukkan pertemuan jurnalisme optimis dengan jurnalisme air mata dalam berita-berita tentang jatuhnya pesawat Sriwijaya Air di okezone dan detik lebih mengutamakan eksploitasi penderitaan korban dan dramatisasi sedangkan aspek-aspek terkait jurnalisme optimis dan mitigasi bencana persentasenya tergolong kecil. Kemudian hasil penelitian ini juga menemukan pemberitaan-pemberitaan pasca jatuhnya pesawat Sriwijaya Air tersebut mayoritas menggunakan sumber berita dari media sosial.
\end{abstract}

Kata-kata Kunci: Jurnalisme optimis; jurnalisme air mata; sumber berita; Sriwijaya Air; analisis media online

\section{Sriwijaya Air 182 news in optimistic and tear journalism perspective}

\section{ABSTRACT}

The crash of Sriwijaya Air 182, optimistic and "tears journalism", and the race to deliver a news story quickly in online media became a foothold and the entry point of this research. This research tries to understand two important concepts, namely "optimistic journalism" and "tears journalism". Optimistic journalism does not exploit the suffering of disaster victims, prioritizes sensitivity to the suffering of disaster victims, the information on disaster mitigation is well considered, the function of media to educate is the main aspect, and optimism for victims becomes the main perspective. While tears journalism is close to exploiting the suffering of disaster victims, it does not prioritize sensitivity to the suffering of disaster victims, lacks attention to disaster mitigation information, lacks the functions to educate, mixing myths with news and does not promote optimism for victims. The purpose of this research was to answer the position of optimistic journalism and tears journalism in online media coverage in Indonesia during the Sriwijaya Air crash in early 2021. The online media selected in this study are detik and okezone. This research uses qualitative methods with the steps coding content and uses Nvivo as an analysis tool. The results of this study showed an optimistic journalism meeting with tears journalism in the news about the crash of Sriwijaya airplane in okezone and seconds prioritize the exploitation of victims'suffering and dramatization. In contrast, aspects related to optimistic journalism and disaster mitigation percentage are relatively small. This study also found that the news after Sriwijaya Air's crash primarily used news sources from social media.

Keywords: Optimistic journalism; tears journalism; news sources; Sriwijaya Air; online media

Korespondensi: Dr. Filosa Gita Sukmono. Universitas Muhammadiyah Yogyakarta, Jl. Brawijaya, Geblagan, Tamantirto, Kec. Kasihan, Bantul, Daerah Istimewa Yogyakarta 55183.Email: filosa@umy.ac.id 


\section{PENDAHULUAN}

Indonesia sering mengalami tragedi dan bencana jatuhnya pesawat terbang dan hal tersebut pasti menyita perhatian banyak pihak, terutama media. Mengapa media? karena media tahu bahwa jatuhnya pesawat mempunyai nilai berita yang tinggi, sehingga hampir semua media di Indonesia berlomba-lomba untuk memberitakan atau lebih tepatnya ingin menjadi yang terdepan dalam menyampaikan berita dan informasi tersebut.

Bencana menurut International Federation of Red Cross and Red Crescent Societies (IFRC) adalah sebuah pristiwa yang datang tiba-tiba dan terjadi secara serius sehingga mengganggu fungsi masyarakat yang diikuti oleh kerugian manusia baik secara material maupun ekonomi yang pada akhirnya membutuhkan cara untuk mengatasinya. Kemudian jika di Indonesia rujukan tentang konsep bencana sendiri adalah Undang-Undang (UU) No. 24 tahun 2007 tentang Penanggulangan Bencana, dimana bencana adalah peristiwa atau rangkaian peristiwa yang mengancam dan mengganggu kehidupan dan penghidupan masyarakat yang disebabkan, baik oleh faktor alam dan atau faktor non alam maupun faktor manusia sehingga mengakibatkan timbulnya korban jiwa manusia, kerusakan lingkungan, kerugian harta benda, dan dampak psikologis. Definisi tersebut menyebutkan bahwa bencana disebabkan oleh faktor alam, non alam, dan manusia. Oleh karena itu, UU No. 24 tahun 2007 tersebut juga mendefinisikan mengenai bencana alam, bencana non alam, dan bencana sosial. Kecelakaan transportasi artinya adalah kecelakaan moda transportasi yang terjadi di darat, laut dan udara.

Jatuhnya pesawat Sriwijaya Air 182 pada 9 Januari 2021 merupakan bencana bangsa di awal tahun 2021 dan merupakan bencana non alam tentang moda transportasi, pemberitaan tentang jatuhnya pesawat ini juga menghiasi berbagai media online nasional. Media online begitu cepat menugaskan tim media sosialnya untuk membuat konten yang merujuk pada beritaberita yang ada dalam media tersebut untuk dibagikan lewat media sosial. Hasilnya dalam sekejap berita-berita tersebut "menghampiri" pembaca media online. Dramatisasi, kesedihan bahkan tangisan air mata menghiasi status banyak orang dengan menampilkan tautan dari media online.

Perlombaan dalam menyampaikan sebuah berita secara cepat ini berdampak kepada hasil sebuah pemberitaan yang terkadang jauh dari nilai-nilai optimisme tetapi fokus pada jurnalisme air mata. Akhirnya terlihat penelitianpenelitian yang fokus pada penderitaan korban dari bencana tersebut bukan bagaimana nilainilai optimisme pasca tragedi atau musibah tersebut.

Membicarakan kesedihan dan optimisme dalam pemberitaan tidak bisa dilepaskan dari jurnalisme optimis dan jurnalisme air mata, Sukmono dan Junaedi menjelaskan tentang jurnalisme optimis dan jurnalisme air mata dalam hasil penelitian yang mereka lakukan di tahun 2018, jurnalisme air mata dekat dengan mengeksploitasi penderitaan korban bencana, tidak memiliki sensitivitas pada penderitaan korban bencana, informasi mitigasi bencana kurang diperhatikan, fungsi edukasi media kurang, mencampurkan mitos dengan berita tidak mengedepankan optimisme pada korban. Jurnalisme optimis sendiri dekat dengan tidak mengeksploitasi penderitaan korban bencana, mengedepankan sensitivitas pada penderitaan korban bencana, informasi mitigasi bencana diperhatikan dengan baik, fungsi edukasi media menjadi aspek utama, optimisme pada korban menjadi perspektif utama (Sukmono \& Junedi, 2018).

Penelitian ini ingin menunjukkan apakah fenomena jurnalisme air mata tersebut ada dalam media-media online di Indonesia atau justru jurnalisme optimis yang mereka tonjolkan. Penelitian ini akan melihat dua media online yang cukup sering dikunjungi oleh masyarakat yaitu okezone.com dan detik.com dalam memberitakan jatuhnya Sriwijaya Air dengan rentan waktu pada 9 Januari sampai 16 Januari 2021. Adapun media yang pilih pada penelitian ini adalah Detik.com dan okezone.com. Pemilihan kedua media ini tidak bisa dilepaskan dari faktor sejarah yaitu pada 1998, Indonesia mencatat kehadiran media online pertama tanpa edisi cetak yaitu, Detik.com. Detik.com ini menjadi pionir media online di Indonesia untuk mengembangkan platform digital. Di tahun 2006, Okezone.com turut meramaikan era media online tanpa versi cetak. Saat itu media ini hadir dengan informasi yang lebih variatif dan berbeda, seperti adanya kemunculan kanal hiburan, gaya hidup, dan olahraga (Nugroho 
et al., 2012) selain itu berdasarkan sejarahnya, kedua media ini adalah media yang lahir tanpa versi cetak. Walaupun kedua media online ini lahir di tahun yang cukup berjarak, keduanya merupakan media yang mampu bertahan di masa ini, setelah sejumlah portal media online ditutup atau menghadapi kesulitan dalam bertahan pada rentang tahun 2003-2008.

Kemudian rentan waktu antara 9 Januari sampai 16 Januari 2021 yang dipilih untuk menganalisis berita-berita yang muncul karena 7 -8 hari pertama sejak jatuhnya pesawat Sriwijaya Air 182 tersebut jumlah pemberitaan cukup banyak di berbagai media dan menjadi perbincangan masyarakat terutama dalam ruang cyber. Sehingga tujuan penelitian ini adalah menunjukkan bagaimana jurnalisme optimis dan jurnalisme air mata "bekerja" pada pemberitaan Sriwijaya Air 182 yang terjadi di awal tahun 2021.

Penelitian ini menggunakan beberapa indikator dalam rangka untuk mencapai tujuan penelitian dan temuan yang diinginkan, indikator pertama yang digunakan dalam penelitian ini adalah poin-poin dalam jurnalisme air mata yaitu mengeksploitasi penderitaan korban bencana, tidak memiliki sensitivitas pada penderitaan korban bencana, Informasi mitigasi bencana kurang diperhatikan, fungsi edukasi media kurang, mencampuradukkan mitos dengan berita, tidak mengedepankan optimisme bagi korban.

Indikator kedua adalah jurnalisme optimis yaitu tidak mengeksploitasi penderitaan korban bencana, sensitivitas pada penderitaan korban bencana, mengedepankan mitigasi bencana, mengedepankan fungsi edukasi media, mitos dipahami sebagai kearifan lokal, optimisme pada korban menjadi perspektif utama.

Indikator ketiga adalah sumber berita, mengapa sumber berita karena di era perkembangan media sosial yang begitu cepat justru media pemberitaan online merujuk status seseorang dalam media sosial untuk dijadikan sumber berita. Hal ini cukup menyita perhatian publik karena media hari ini sudah semakin jauh dari nilai-nilai jurnalistik.

Jurnalisme sendiri secara konseptual adalah proses pencarian sampai mempublikasikan sebuah berita berdasarkan data dan fakta yang ada di lapangan, permasalahannya hari ini adalah banyak berita yang bukan berdasarkan data dan fakta tetapi justru dari opini atau status seseorang dalam media sosial. Sehingga penelitian ini menjadi penting untuk diteliti karena tidak hanya melihat tentang jurnalisme optimis dan jurnalisme air mata tetapi juga pada indikator ketiga yaitu melihat dari aspek sumber berita yang merupakan permasalahan media online akhir-akhir ini.

Penelitian ini menawarkan hal yang baru terkait jurnalisme optimis dan jurnalisme air mata dalam media online dengan juga dielaborasikan hasil analisis tentang fenomena sumber berita dalam media online, karena penelitian-penelitian sebelumnya melihat dari sudut pandang maupun objek penelitian yang berbeda terkait media online maupun jurnalisme bencana. Hasil penelitian tentang pemberitaan di media online untuk pengurangan risiko bencana Gunung Sinabung menemukan bahwa waktu tayang berita di kedua media lebih dominan berita pada periode pasca bencana dibandingkan periode bencana lainnya seperti periode pra bencana dan periode tanggap darurat (Lestari et al., 2018), kemudian penelitian tentang media online tentang bagaimana penyebaran rumor online di Weibo, WeChat, dan situs berita arus utama tiga platform berita online utama di China (Guo \& Zhang, 2020), penelitian lainya fokus pada analisis berita yang diterbitkan di situs online CNN, Al-Jazeera English, dan Sputnik untuk menyelidiki bagaimana outlet berita transnasional membingkai penderitaan manusia yang terkait dengan perang Suriah (Zhang \& Luther, 2020). Penelitian lain fokus mengulas relevansi konsep jurnalisme digital dengan praktik jurnalisme. Sebagai sebuah konsep, jurnalisme dan digital memiliki pengertian yang berbeda. Jurnalisme memiliki makna dengan cakupan aktivitas yang luas, mulai dari aktivitas mencari, mengolah dan menyebarkan informasi kepada publik (Ashari, 2019), kemudian hasil penelitian lainnya menjelaskan bahwa liputan media online tentang program vaksinasi HPV Afrika Selatan pada umumnya positif dengan informasi yang akurat tetapi terkadang tidak lengkap (Attipoe-Dorcoo et al., 2018). Selain itu terdapat penelitian tentang bisnis berita dan media online yang mana media berita swasta di seluruh dunia mencoba mengembangkan model pembayaran untuk berita. Namun, pemahaman kami tentang apa yang mendorong perilaku dan sikap untuk membayar berita online tetap terbatas (Fletcher \& Nielsen, 2017), kemudian penelitian tentang bagaimana media online 
membingkai penembakan polisi terhadap Tamir Rice yang berusia 12 tahun di Cleveland, $\mathrm{OH}$. Penelitian ini melakukan analisis konten kualitatif dari sampel besar artikel berita online yang diterbitkan dalam 48 jam pertama setelah acara. Penelitian ini mempertimbangkan bagaimana media online menggunakan tajuk berita, narasi, kutipan, dan gambar untuk membingkai berita yang muncul ini. penelitian ini menemukan bahwa media berita online membingkai penembakan Beras dengan cara yang sebagian besar mendukung narasi resmi polisi dari peristiwa tersebut (Stone \& Socia, 2019), terakhir penelitan dengan fokus media online di Inggris yang tidak proporsional pada 'pesta minuman keras' wanita bertentangan dengan bukti epidemiologi, dapat mereproduksi stereotip gender yang berbahaya dan dapat menghalangi pemahaman publik tentang batas konsumsi mingguan netral gender dalam pedoman alkohol yang baru diusulkan (Patterson et al., 2016).

\section{METODE PENELITIAN}

Penelitian kualitatif berbasis konten berkontribusi terhadap kondisi manusia dalam situasi apapun, sehingga perlu memahami kondisi tersebut dengan desain yang kontekstual (Bengtsson, 2016). Agar dapat melihat kondisi tersebut maka analisis kualitatif konten melalui tahapan analisis mengklasifikasikan informasi tentang situasi atau kondisi saat itu (Karlsson \& Sjøvaag, 2016).

Penelitian ini menggunakan metode kualitatif, metode kualitatif dalam penelitian media berfungsi untuk menganalisis isi dari konten digital (Karlsson \& Sjøvaag, 2016, sehingga metode kualitatif berfungsi untuk mendeskripsikan hasil dari konten media digital (Hamilton \& Finley, 2019). Melalui metode kualitatif maka analisis media menggunakan steps coding conten (Neuendorf, 2017), oleh karena itu penelitian ini menggunakan Nvivo

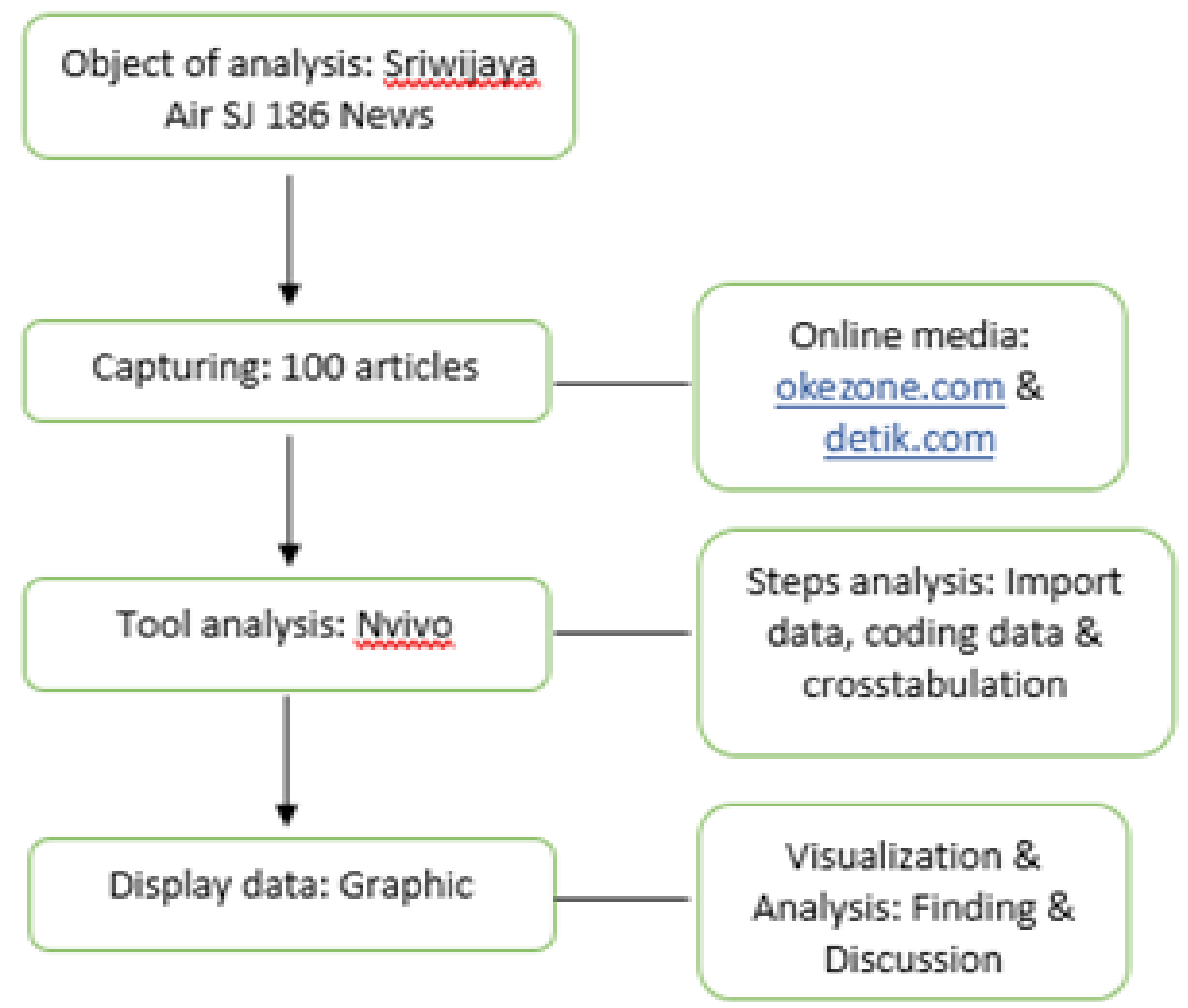

Sumber : Hasil Olahan Peneliti, 2021

Gambar 1 Tahapan Analisis Media Online 
sebagai alat analisis AlYahmady \& Al Abri (2013). Fungsi Nvivo pada penelitian kualitatif untuk menstrukturkan data melalui proses coding, atau sebagai alat management data (Bandara, 2006). Penggunaan Nvivo dalam penelitian ini sebagaimana pandangan Bandara, sebagai alat manajemen data, maka tahapan penggunaan Nvivo sebagai alat analisis terbagi menjadi empat tahap analisis; (1) menentukan objek penelitian, (2) capturing articles, (3) analysis, (4) display data.

Pengambilan data menggunakan fiture $\mathrm{N}$-capture pada google.com dengan memilih article pada media online Okezone.com dan Detik.com. Langkah kedua adalah import data, coding data dan cross tabulation. Pada tahapan coding merujuk pada landasan teori yang telah ditentukan sebelumnya, sehingga display data terstruktur antara satu media dengan media atau indikator dengan indikator. Step analisis menggunakan Nvivo untuk menjelaskan Nvivo bekerja pada penelitian kualitatif (Woolf \& Silver, 2018).

Hasil coding ditampilkan dalam bentuk grafik dan gambar pada masing-masing indikator dan media online. Penelitian ini juga mengikuti tahapan analisis konten pada penelitian kualitatif (Bengtsson, 2016), sehingga tahapan analisis pada penelitian ini dapat dijelaskan pada gambar 1 .

\section{HASIL DAN PEMBAHASAN}

Penelitian ini menguraikan temuan berdasarkan jurnalisme sensitif bencana yang terbagi menjadi dua yaitu jurnalisme air mata dan dan jurnalisme optimis, keduanya melihat bagaimana peran dan fungsi media dalam memberikan informasi tentang suatu kondisi. Berdasarkan analisis Nvivo terhadap indikator jurnalisme air mata pada media online Detik. com dan okezone.com, pemberitaan terhadap Sriwijaya Air 182 memiliki perbedaan masingmasing. Informasi yang disampaikan oleh kedua media online tersebut memiliki tipe informasi dalam melaporkan suatu bencana. Hasil coding 100 artikel yang dipublikasi oleh kedua media tersebut menunjukkan bahwa informasi yang disampaikan memiliki kategori yang berbedabeda, pada grafik di bawah pemberitaan tentang Sriwijaya Air 182 meliputi tema, (1) eksploitasi

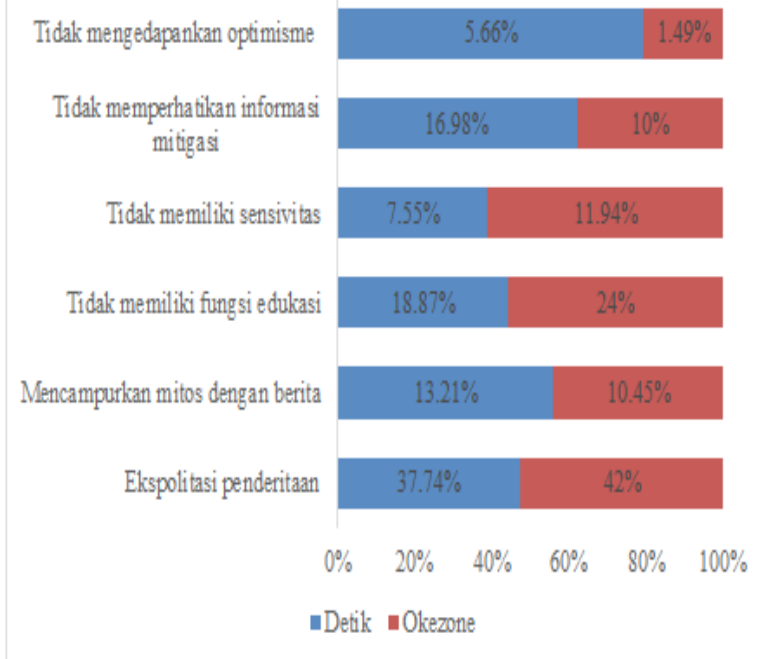

Sumber: Analisis Nvivo, 2021

Gambar 2 Jurnalisme Optimis dalam Pemberitaan Sriwijaya Air 182

penderitaan korban; (2) mencampurkan mitos dan fakta; (3) tidak memiliki fungsi edukasi; (4) tidak memiliki sensitivitas; (5) tidak memperhatikan informasi mitigasi; dan (6) tidak mengedepankan optimisme.

Publikasi informasi oleh kedua media tersebut memiliki perbedaan berdasarkan kategori informasi. Pertama, aspek jurnalisme air mata dengan sudut pandang eksploitasi penderitaan korban di Detik.com dengan persentase $37,74 \%$ dan Okezone.com 42\%. Kedua, mencampurkan mitos dengan fakta yang mana Detik.com 13,21\% Okezone. com 10,45\%. Ketiga, Detik.com memperoleh persentase 18,87\% dan Okezone.com 24\% untuk aspek tidak memiliki fungsi edukasi. Keempat, Detik.com memperoleh persentase 7,55\% dan Okezone.com 11,94\% pada aspek tidak memiliki sensitivitas. Kelima, pada aspek tidak memperhatikan informasi mitigasi Detik. com memiliki persentase $16,98 \%$ dan $10 \%$ untuk Okezone.com. Keenam, Detik.com tidak mengedepankan optimisme dengan perolehan angka sebanyak 5,66\% dan Okezone.com $1,49 \%$.

Jurnalisme optimis adalah informasi yang disampaikan dengan mempertimbangkan kaidah jurnalistik, informasi yang disampaikan berupa upaya optimisme terhadap kondisi yang sedang 


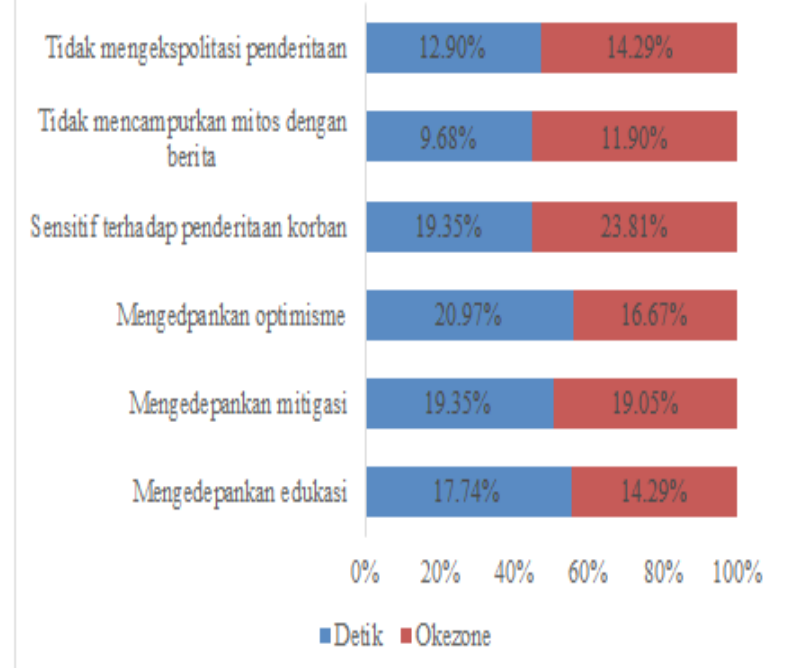

Sumber: Analisis Nvivo, 2021

\section{Gambar 3 Jurnalisme Air Mata dalam Pemberitaan Sriwijaya Air 182}

terjadi. Berdasarkan hasil analisa terhadap pemberitaan Sriwijaya Air 812 maka aspek jurnalisme optimis detik.com dan aokezone. com dengan persentase sebagai berikut. Pertama mengedepankan edukasi: detik.com $(17,74 \%)$, okezone.com (14,29\%), kedua mengedepankan mitigasi detik.com (19,35\%), okezone.com (19.05), ketiga mengedepankan optimisme detik.com (20,97\%), okezone.com $(16,67 \%)$, keempat sensitif terhadap penderitaan detik. com (19.35\%), okezone.com (23,81\%), kelima tidak mencampurkan mitos dengan berita detik. com $(9,68 \%)$ okezone.com $(11,90 \%)$, keenam tidak mengeksploitasi penderitaan detik.com (12.90\%), okezone.com $(14,29 \%)$.

Pemberitaan yang dilakukan oleh kedua media online tersebut menggunakan sumber informasi yang berbeda-beda, penggunaan sumber tersebut menunjukkan kualitas informasi yang diberikan. Oleh karena itu, penelitian ini juga mengklasifikasikan sumber informasi oleh kedua media tersebut. Berdasarkan tahapan analisis Nvivo maka kedua media tersebut menggunakan sumber informasi yang beragam dalam memberitakan Sriwijaya Air 182. Di antara Detik.com dan okezone.com menggunakan kanal sumber informasi dengan persentase yang berbeda-beda.

Sumber informasi pertama melalui rilis pers yang mana Detik.com dengan persentase $19,78 \%$ dan Okezone.com 21,13\%. Sumber informasi kedua yaitu peristiwa di lapangan yang mana Detik.com 18,68\% dan Okezone. com $12,68 \%$. Sumber informasi ketiga melalui media sosial dengan persentase dari Detik.com 20,88\% dan Okezone.com 30,99\%. Sumber informasi keempat melalui korban bencana memperoleh persentase $20,88 \%$ dan $30,99 \%$ pada masing-masing media online Detik. com dan okezone.com. Sumber informasi kelima melalui konferensi pers, Detik.com memperoleh persentase $24,18 \%$ dan Okezone. com dengan persentase $18,31 \%$. Terakhir, sumber informasi keenam melalui Badan Nasional Penanggulangan Bencana (BNPB) dengan perolehan persentase dari Detik.com dan okezone.com masing-masing $15,38 \%$ dan $11,27 \%$.

Gambar 4 menjelaskan bahwa sumber informasi dengan persentase tinggi adalah dari media sosial, baik itu Detik.com maupun Okezone.com. Kedua media online ini menggunakan media sosial sebagai sumber utama dalam mengemas sebuah berita terkait Sriwijaya Air 182. Sumber informasi terbesar selanjutnya adalah melalui konferensi pers dan kanal ini menjadi sumber informasi terbesar pertama secara real time bagi Detik.com dan okezone.com. Kemudian, sumber informasi terbesar selanjutnya adalah rilis pers.

Selain melihat informasi dan konten yang diberitakan melalui analisis Nvivo, tulisan ini juga menganalisis korelasi antara informasi yang disampaikan dengan sumber

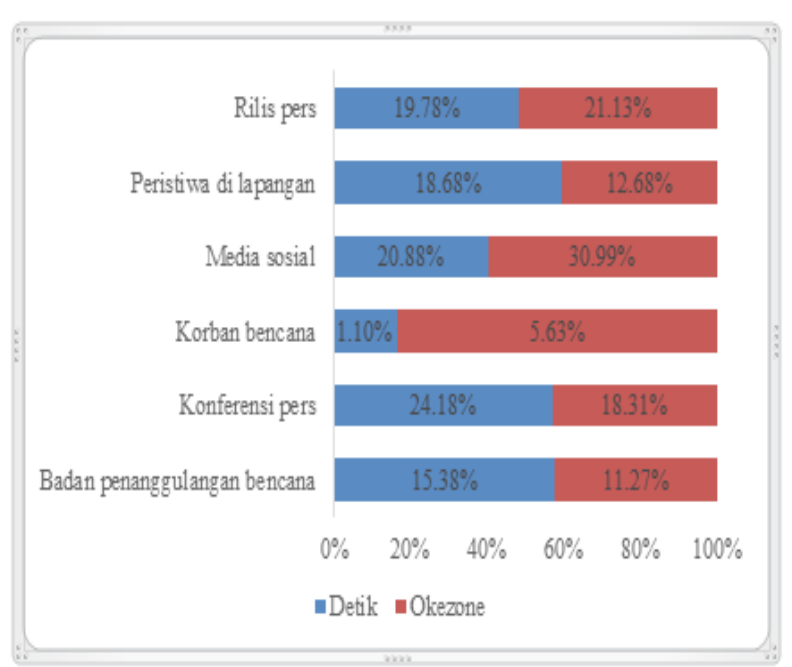

Sumber: Analisis Nvivo, 2021

Gambar 4 Sumber Informasi dalam Pemberitaan Sriwijaya Air 182 
Tabel 1 Analisis Korelasi Antara JurnalismeAir Mata dan Sumber Informasi

\begin{tabular}{lll}
\hline Sumber Informasi (A) & Jurnalisme Air Mata (B) & Sørensen's coefficient \\
\hline Media sosial & Eksploitasi penderitaan & 0,772201 \\
Media sosial & Tidak memiliki fungsi edukasi & 0,653226 \\
Media sosial & Tidak memperhatikan informasi mitigasi & 0,554591 \\
Rilis pers & Tidak memiliki fungsi edukasi & 0,508664 \\
Rilis pers & Eksploitasi penderitaan & 0,470037 \\
Media sosial & Mencampurkan mitos dengan berita & 0,449351 \\
Peristiwa di lapangan & Eksploitasi penderitaan & 0,448921 \\
Peristiwa di lapangan & Tidak memiliki fungsi mitigasi & 0,428831 \\
Media sosial & Tidak memiliki sensivitas & 0,387013 \\
\hline
\end{tabular}

Sumber: Analisis Nvivo, 2021

berita yang digunakan berdasarkan kategori berita masing-masing. Lihat Tabel 1, adalah analisis Correlation Coefficient Sørensen〉s, yang berfungsi untuk melihat kesamaan antara sumber informasi dan jurnalisme air mata (A \& B), analisis correlation melihat hubungan antara A \& B dengan nilai yang paling tinggi. Tabel di bawah menjelaskan bahwa sumber informasi memiliki hubungan dengan indikator jurnalisme air mata dengan nilai: media sosial dan eksploitasi penderitaan 0,77 , media sosial dan tidak memiliki fungsi edukasi 0,65, media sosial-tidak memperhatikan informasi mitigasi 0,55 . Sehingga penelitian ini menjelaskan bahwa sumber informasi yang diperoleh melalui media sosial adalah informasi yang bersifat eksploitatif, tidak memiliki fungsi edukasi, dan tidak memperhatikan informasi mitigasi bencana. Tetapi penggunaan media sosial sebagai sumber informasi menciptakan sensitivitas, hal ini dikarenakan informasi yang disampaikan berkaitan dengan sikap dan rasa duka kepada korban.

Analisis korelasi dalam penelitian ini juga melihat hubungan antara (A \& $\mathrm{C}$ ), analisis Correlation Coefficient Sørensen's pada (A \& C) melihat hubungan antara sumber informasi dan indikator jurnalisme optimis. Tabel di bawah menjelaskan bahwa pada indikator jurnalisme optimis sumber informasi yang sering dirujuk dari BNPB dengan nilai: BNPB dan mitigasi 0,75, BNPB dan optimisme 0,66, konferensi pers dan mitigasi 0,63. Pada indikator jurnalisme optimis informasi yang disampaikan bersumber dari BNPB, dan konferensi pers, kedua sumber informasi tersebut merupakan informasi real time yang diperbaharui secara langsung oleh pihak pertama yang terlibat secara langsung dalam penanganan bencana dan korban Sriwijaya Air 182.

Tabel 1 dan 2 memiliki perbedaan berdasarkan korelasi yang paling tinggi, pada tabel 1 jumlah korelasi antara A \& B berjumlah (4), sedangkan pada tabel 2 jumlah korelasi A \& C berjumlah (9). Artinya informasi yang disampaikan oleh kedua media tersebut cenderung menggunakan sumber informasi yang real-time yang disampaikan secara langsung oleh BNPB dan melalui konferensi pers baik yang dilakukan oleh pemerintah, tim SAR dan sebagainya, sumber informasi tersebut merupakan informasi yang bersifat optimis. Sedangkan jurnalisme air mata dengan korelasi rendah, baik itu jumlah korelasi maupun nilai korelasi.

Berita yang disampaikan oleh kedua media berkaitan dengan informasi Sriwijaya Air 182, analisis Word Cloud pada 100 artikel kedua media online tersebut menunjukkan bahwa informasi tersebut berkaitan. Lihat analisis Word Cloud pada Gambar 1. Konten Berita Sriwijaya Air 182, penyebutan terbanyak seperti; Sriwijaya Air (267), pesawat (453), korban (355), SJ 182 (221), keluarga (216), 2021 (195), Jakarta (179), jenazah (173), jatuhnya (107). Jumlah tersebut berdasarkan penyebutan terbanyak sebanyak $\geq$ (lebih dari) 100 kali dalam pemberitaan oleh kedua media tersebut. Di sisi lain, penyebutan dengan angka $\leq$ (kurang dari) 100 seperti; Pontianak (95), video 
Tabel 2 Analisis Korelasi Antara Jurnalisme Optimis dan Sumber Informasi

\begin{tabular}{lll}
\hline Sumber Informasi (A) & Jurnalisme Air Mata (B) & Sørensen's coefficient \\
\hline BNPB & Mengedepankan mitigasi & 0,750191 \\
BNPB & Mengedepankan optimisme & 0,667742 \\
Konferensi pers & Mengedepankan mitigasi & 0,630982 \\
Konferensi pers & Mengedepankan edukasi & 0,592488 \\
Peristiwa di lapangan & Mengedepankan mitigasi & 0,590613 \\
Konferensi pers & Mengedepankan optimisme & 0,580645 \\
Peristiwa di lapangan & Mengedepankan optimisme & 0,548805 \\
Konferensi pers & Tidak mengeksploitasi penderitaan & 0,535839 \\
BNPB & Tidak mencampurkan mitos dengan berita & 0,504744 \\
Media sosial & Sensitif terhadap penderitaan korban & 0,483221 \\
\hline
\end{tabular}

Sumber: Analisis Nvivo, 2021

(90), pencarian (87), kecelakaan (82), pilot/ kapten (77), pramugari (70). Konten tersebut menunjukkan informasi yang dipublikasikan oleh Detik.com dan okezone.com dalam kurun waktu tragedi Sriwijaya Air 182, dan hal tersebut memiliki hubungan dengan jurnalisme bencana.

Berdasarkan hasil penelitian di atas, penulis melihat banyak poin menarik dari detik.com dan okezone.com dalam membingkai berita tragedi khususnya terkait dengan jurnalisme air mata jatuhnya pesawat Sriwijaya Air 182. Jurnalisme air mata sendiri dekat dengan mengeksploitasi penderitaan korban bencana, tidak memiliki sensitivitas pada penderitaan korban bencana, informasi mitigasi bencana kurang diperhatikan, fungsi edukasi media kurang, mencampurkan mitos dengan berita tidak mengedepankan optimisme pada korban.

Melihat data di atas maka kedua media online ini sama-sama mengeksploitasi penderitaan korban, hal ini terbukti tingginya angka presentasi eksploitasi penderitaan korban. Eksploitasi penderitaan korban ini sebenarnya merupakan wajah "kusam" pemberitaan media Indonesia ketika terjadi bencana, praktik jurnalisme di Indonesia saat ini cenderung mengutamakan sudut pandang penderitaan korban, dramatis, traumatis, dan eksploitatif dibandingkan nilai-nilai informatif dari sebuah jatuhnya pesawat. Kecenderungan media saat ini untuk melakukan praktik dramatisasi korban adalah untuk kepentingan industri media
(Nazaruddin, 2015)

Industri media seakan-akan mengetahui bahwa yang ingin dilihat dan dibaca oleh masyarakat setiap terjadi bencana adalah tangisan kesedihan darikorban, hal ini sangat erat kaitannya dengan budaya masyarakat kita yang masih memiliki cara pandang sinetronisasi yang menginginkan banyak dramatisasi kejadian, hal ini sejalan dengan data yang dikeluarkan oleh KPI tahun 2020 bahwa $60 \%$ masyarakat kita masih senang menonton sinetron. Fenomena ini seperti adanya penawaran dan permintaan, selama berita tentang eksploitasi korban masih tinggi jumlah pembacanya maka hal ini akan terus berlanjut, artinya kembali lagi kepada literasi media.

Kemudian aspek tidak memiliki sensitivitas pada penderitaan korban bencana juga cukup dominan dalam pemberitaan tentang bencana, dimana dalam jatuhnya pesawat Sriwijaya Air okezone memiliki persentase yang cukup tinggi dibandingkan dengan detik.com. Ketidak sensitivitas an ini terjadi karena banyaknya berita yang justru mengungkap "sisi lain" dari korban dalam kehidupannya. Berita-berita tersebut untuk media akan meningkatkan jumlah pembaca, tetapi untuk keluarga korban justru semakin "menyakiti" dan membuka berbagai kenangan tentang korban tersebut. Bayangkan jika berita-berita yang tidak sensitif terhadap korban tersebut dibaca oleh anak atau keluarga terdekat.

Kemudian terkait informasi mitigasi 
bencana yang kurang diperhatikan justru persentasenya lebih tinggi detik.com. Dibalik itu semua media sebenarnya harus lebih memperhatikan informasi tentang mitigasi bencana karena hal tersebut bisa membangun kesadaran masyarakat tentang bencana dan mengurangi resiko bencana dikemudian hari khususnya terkait moda transportasi udara.

Menyambung dengan informasi mitigasi secara umum kedua media ini kurang memberikan edukasi yang baik terkait pemberitaan bencana, dan okezone.com persentasenya cukup tinggi dibandingkan detik.com. Pemberitaan yang mengandung edukasi yang baik sebenarnya cukup penting dalam mengurangi masyarakat yang semakin ketakutan terhadap moda transportasi tertentu. Seperti banyaknya kejadian dimana banyak dari masyarakat yang trauma memilih transportasi tertentu karena kurangnya pemberitaan memiliki edukasi yang baik.

Terakhir aspek jurnalisme sensitif bencana adalah mencampurkan mitos dengan fakta, yang cukup mengejutkan yang tinggi justru dari detik.com yang merupakan salah satu media online paling lama beredar di Indonesia. Beritaberita bencana yang banyak mengandung mitos justru semakin mengaburkan fakta dan membuat masyarakat mengalami kebingungan. Masih segar dalam ingatan ketika letusan gunung merapi beberapa tahun yang lalu salah satu media nasional mencampurkan mitos dengan fakta yang membuat warga Yogyakarta menjadi panik dan akhirnya acara di media tersebut "diturunkan" oleh KPI karena mendapatkan banyak aduan dari masyarakat.

Kemudian terkait jurnalisme optimis baik detik.com dan okezone.com sama-sama menunjukkan persentase yang minim, bahkan aspek mengedepankan optimisme hanya 20 $\%$. Sebenarnya jurnalisme optimis merupakan praktik jurnalisme yang mengedepankan kepentingan korban dan masyarakat untuk bersama-sama bangkit pasca bencana, bahkan Sukmono dan Junaedi menegaskan jurnalisme optimis merupakan bagian dari profesionalitas seorang jurnalis dalam proses peliputan berita (Sukmono \& Junedi, 2018).

Kemudian aspek menarik dari jurnalisme optimis dan jurnalisme air mata ini adalah terkait sumber berita, karena sumber berita dalam pemberitaan hari ini menjadi sorotan oleh masyarakat luas karena masyarakat mulai sadar ketika membaca berita, banyak sumber berita bukan dari sumber primer melainkan sumber sekunder. Data di atas menunjukkan terdapat enam jenis sumber berita yang digunakan oleh detik.com dan okezone.com dalam mengolah berita jatuhnya Sriwijaya Air 182 yaitu perolehan dari rilis pers, peristiwa di lapangan, media sosial, korban bencana, konferensi pers, dan BNPD.

Pada lanskap jurnalisme air mata, media sosial adalah sumber informasi utama yang digunakan kedua media online ini dalam mengolah berita. Lima dari enam poin atau sudut pandang dalam pembingkaian berita Sriwijaya Air 182 mewarnai berita yang didapatkan dari media sosial yaitu mencakup, eksploitasi penderitaan, tidak memiliki fungsi edukasi, tidak memperhatikan informasi mitigasi, mencampurkan mitos dengan berita, tidak memiliki sensitivitas. Perolehan informasi dari media sosial dengan hasil berita yang tidak normatif ini sangat disayangkan dan tidak wajar, terlebih mengingat peristiwa yang dibingkai adalah sebuah kecelakaan atau bencana. Salah satu contoh yang masih jelas adalah dimana salah satu korban jatuhnya pesawat Sriwijaya Air adalah salah satu Youtuber yang mana akhirnya banyak status di media sosial dari korban tersebut dijadikan sumber berita oleh banyak media, bahkan termasuk komentar netizen dalam akun media sosial tersebut-pun dijadikan berita.

Berdasarkan data memang terlihat bahwa okezone.com lebih banyak memunculkan berita jatuhnya pesawat Sriwijaya Air yang mencapai $33,99 \%$. Jika dikaji hal ini bisa sebagai salah satu cara media untuk mendekatkan berita dengan pembaca dengan mengambil sudut pandang akun media sosial, tetapi dari sudah pandang jurnalisme hal ini kurang baik.

Sementara pada lanskap jurnalisme optimis, konferensi pers adalah sumber utama dalam mengolah informasi. Adapun perolehan berita yang dibingkai yaitu berdasarkan sudut pandang yang mengedepankan mitigasi, mengedepankan edukasi, mengedepankan optimisme, dan tidak mengeksploitasi penderitaan korban. Pada dasarnya, olahan berita ini bersifat optimis bagi keluarga korban maupun masyarakat. Begitu juga dengan perolehan informasi dari BNPB dan peristiwa di lapangan, berita yang dihasilkan tidak mengandung bumbu-bumbu kesedihan. 
Berdasarkan data yang di dapat memang terlihat detik.com lebih banyak mengambil sumber berita dari konferensi pers yaitu 24, 18 $\%$. Hal ini memang membuat berita lebih riil tanpa ada dramatisasi di dalamnya karena data yang muncul adalah dari pihak yang berwenang termasuk biasanya berisi berbagai himbauan yang mengarah pada banyak hal terkait mitigasi bencana dan berita yang mengandung edukasi.

Penulis merangkum beberapa temuan lainnya terkait penyebab terjadinya ketidakoptimalan dari realisasi jurnalisme optimis di Indonesia yaitu, (1) rendahnya kapabilitas reporter/jurnalis yang mengaburkan batasan antara fakta dengan substansi bencana, (2) minimnya perhatian dan kesadaran jurnalis terhadap kepentingan publik yang berfokus pada drama peristiwa (Astuti, 2011), (3) pemberitaan mencampuradukkan antara fakta dengan mistik dan klenik (Junaedi, 2011), dan (4) berita cenderung eksploitatif pada korban (Arif, 2010)

Peran penting aktor media melalui peristiwa bencana seharusnya mampu; (1) mengedukasi khalayak, (2) meningkatkan kesadaran publik, (3) menghadapi bencana dan melakukan evakuasi, dan (4) berkontribusi dalam proses rekonstruksi pasca-bencana (Rattien, 1990). Peran-peran positif dan penting aktor media ketika terjadi bencana memang kurang terlihat dalam pemberitaan jatuhnya Sriwijaya Air, khususnya dua media online yang diangkat dalam penelitian ini. Data-data yang ditemukan dari berita yang mereka munculkan lebih menonjolkan eksploitasi kesedihan korban, sedangkan aspek-aspek yang sifatnya mengedukasi khalayak memang kurang terlihat dan bukan skala prioritas dari detik.com dan okezone.com.

Jurnalis tidak hanya sekedar berperan untuk menyebarluaskan berita bencana, tetapi juga seharusnya menginformasikan terkait upaya untuk menghadapi bencana dan mengurangi resiko yang memungkinkan terjadi. Hal yang dikhawatirkan terjadi bukanlah mendorong praktik jurnalisme yang optimis, melainkan menjadi bencana jurnalisme (Ahmad, 2010) Tidak hanya di Indonesia, hal ini juga terjadi di Amerika dan Eropa bahwa seringkali media memberitakan peristiwa bencana menggunakan perspektif korban (Houston et al., 2012; Pantti, 2010). Pada hal ini media dianggap gagal dalam menyelami peristiwa bencana yang bahkan terkadang memperkeruh situasi (Sanusi, 2018).

Sebenarnya profesionalitas seorang wartawan akan terlihat dalam keadaan bencana jika memperhatikan beberapa hal antara lain melakukan riset sebelum wawancara, riset ini bisa dilakukan dengan membaca berbagai referensi terkait kejadian bencana sebelum memasuki lokasi bencana. Hal ini untuk mengurangi munculnya berita tentang bencana yang mencampurkan antara fakta dan mitos, karena ketika wartawan telah membaca referensi terlebih dahulu maka mereka lebih paham mana yang fakta mana yang cuma mitos.

Kemudian menyusun pertanyaan dengan baik, artinya bisa menyusun pertanyaan secara menyeluruh mulai dari hal yang mendasar sampai ke pertanyaan pokok. Hal ini untuk mengurangi berita-berita yang kurang sensitif terhadap korban, karena informasi yang didapatkan menyeluruh tidak sepotong-potong.

Mempersiapkan alat liputan adalah kunci berikutnya, karena jika alat liputan tidak dipersiapkan dengan baik maka kualitas berita kurang maksimal dan membahayakan wartawan jika dalam kondisi atau keadaan bencana. Kemudian yang terakhir adalah seorang wartawan harus berani mengambil keputusan terutama di lokasi bencana, keputusan ini juga terkait mana data yang harus kejar mana yang tidak, kembali lagi data yang dikejar harus yang benar-benar sensitif terhadap korban bencana bukan mengekploitasi korban.

Mengambil kasus dari jatuhnya pesawat Sriwijaya Air di awal tahun 2021 terlihat bahwa para jurnalis di Indonesia hanya menjalankan fungsinya sebagai penyebar berita bencana bukan menjalankan tugas untuk mengurangi resiko pasca terjadinya bencana, hal ini merujuk dari hasil analisis pemberitaan detik.com dan okezone.com.

Kini, jurnalis yang dulu hanya menjalankan praktek gatekeeping harus menjalankan peran sebagai gatewatching juga karena komunitas baru yang didirikan hasil dari internet (Bruns, 2011). Praktik gatewatching melibatkan pengguna media sebagai kuratornya. Praktik jurnalisme ini jarang memiliki kejelasan urutan dan alur. Untuk itu, kurasi dituntut untuk menyeleksi informasi dan konten terbaik. Kurasi media sosial dengan demikian harus didasarkan pada upaya yang solid dalam mengelola informasi dengan lebih holistik proses identifikasi, seleksi, verifikasi, 
pengorganisasian, penggambaran, konservasi, dan integrasi (Sundari \& Salamah, 2019). Namun, pada konteks Sriwijaya Air 182 ini, jurnalis seolah-olah melupakan peran dan etika ini sehingga berakibat pada banyaknya berita yang dibingkai secara tidak normatif. Fungsi jurnalis sebagai 'anjing pengawas' lambat laun menjadi 'anjing penuntun', yang banyak berperan dalam mengarahkan masyarakat untuk mendapatkan informasi yang benar (Cui \& Liu, 2017).

Wajah jurnalisme kontemporer mengalami pergeseran budaya yang dikatakan cukup ekspresif karena cukup mengisi "ruang publik emosional" (Richards, 2007). Tidak hanya itu, era digital telah mengantarkan platform dan genre ekspresi baru bagi lanskap jurnalisme melampaui praktik objektif, sehingga melahirkan jurnalisme yang personal, subjektif, dan emosional (Wahl-Jorgensen, 2014). Transformasi dalam jurnalisme ini dikarenakan adanya sifat "multi-epistemik" wacana publik yang dihasilkan dari perubahan teknologi dan sosial (Dahlgren, 2013).

Praktik jurnalisme "kesedihan" ini mengaburkan batasan antara privasi dan publik (Papacharissi, 2014). Misalnya, informasi yang seharusnya hanya untuk keluarga korban kini menjadi hidangan bersama untuk dapat menikmata rasa sedih tersebut bersama-sama. Subjektifitas, ekspresi emosional, dan sejarah pribadi dipandang tidak relevan dan berada di luar cakupan topik yang dapat diterima publik. Hal ini cenderung mewakili "objek buruk" bagi praktisi jurnalisme dan dipahami sebagai hal yang menyimpang dari ruang publik (Coward, 2013; Pantti, Wahl-Jorgensen \& Cottle, 2012). Ketiga hal ini mewakili penurunan standar jurnalisme dan penyimpangan dari peran sosial jurnalisme yang tepat. Di sisi lain, jurnalisme optimis menginformasikan dan mendidik masyarakat, bukan memanjakan pembaca dengan informasi yang menarik emosi (Pantti, 2010).

"Politik kasihan" ini dibuat agar pembaca juga turut merasakan hal yang dialami oleh korban. Secara epistimologis hal ini tidak salah, namun interpretasi "sentimen" ini secara normatif adalah hal yang tidak wajar dan menjadi masalah (Cottle, 2013; Matheson, 2004; Andrejevic, 2011). Kisah miris yang dianggap menyayat hati dan mampu mengundang kesedihan adalah komoditas yang dijual oleh jurnalis dalam praktik jurnalisme air mata. Hal ini dapat dikatakan bahwa pelajaran berharga yang dibingkai oleh jurnalis dibalik jatuhnya Sriwijaya Air 182 kebanyakan hanyalah berita-berita yang dianggap mampu mengundang 'rasa kasihan' pada korban, bukan fakta dan upaya terkait kebencanaannya. Pada konteks ini, berita tidak lagi bersifat informatif, melainkan menjadi dramatis berdasarkan konstruksi yang dibangun oleh aktor media dalam memberitakan suatu bencana.

\section{SIMPULAN}

Berdasarkan penjelasan di atas, maka penelitian ini menyimpulkan bahwa media online dalam memberitakan kondisi bencana banyak mengundang perhatian masyarakat. Hal ini dibuktikan dengan data yang sudah dipaparkan dalam penelitian ini yaitu selama satu minggu pasca jatuhnya pesawat tersebut masyarakat dibuat larut dalam berbagai kesedihan yang dialami keluarga korban.

Penelitian ini menjawab fenomena besar di awal tahun 2021 terkait pemberitaan jatuhnya pesawat Sriwijaya Air 182 yaitu dengan mempertemukan jurnalisme optimis dengan jurnalisme air mata dalam pemberitaan di media, hasilnya media online khususnya okezone dan detik lebih mengutamakan eksploitasi penderitaan korban dan dramatisasi sedangkan aspek-aspek terkait jurnalisme optimis dan mitigasi bencana persentasenya kecil. Meminjam istilah Ahmad Arif salah satu jurnalis senior kompas, hal inilah yang membuat jurnalisme bencana menjadi bencana jurnalisme.

Berdasarkan hasil penelitian ini juga ditemukan pemberitaan-pemberitaan pasca jatuhnya pesawat Sriwijaya Air tersebut mayoritas menggunakan sumber berita dari media sosial. Misal status keluarga korban di media sosial atau bahkan update status terakhir korban sebelum peristiwa tersebut.

Saran untuk penelitian selanjutnya adalah dengan mengembangkan kajian dengan perspektif kritis agar bisa melihat sejauh mana kepentingan pemilik modal dalam memengaruhi isi berita dalam situasi bencana, terutama bagaimana komodifikasi kesedihan dalam pemberitaan yang relasinya langsung kepada "hidup" sebuah media massa. 


\section{DAFTAR PUSTAKA}

Ahmad, A. (2010). Jurnalisme bencana, bencana jurnalisme. Jakrarta : Kompas.

AlYahmady, H. H., \& Al Abri, S. S. (2013). Using nvivo for data analysis in qualitative research. International Interdisciplinary Journal of Education, 2(2), 181-186. https://doi.org/10.12816/0002914

Andrejevic, M. (2011). The work that affective economics does. Cultural Studies, 25(4-5), 604-620. https://doi.org/10.1080/0950238 6.2011 .600551

Ashari, M. (2019). Jurnalisme digital: dari pengumpulan Informasi Sampai Penyebaran Pesan. Inter Komunika : Jurnal Komunikasi, 4(1), 1-16. https://doi. org/10.33376/ik.v4i1.286

Astuti, S. (2011). Kabar bencana di layar kaca: beberapa catatan terhadap pemberitaan letusan Merapi 2010 di televisi Indonesia (Setio Budi HH (ed.). Yogyakarta : Aspikom dan Buku Litera.

Attipoe-Dorcoo, S., Singh, V., \& Moodley, J. (2018). A content analysis of online news media reporting on the human papillomavirus vaccination programme in South Africa. Southern African Journal of Gynaecological Oncology, 10(2), 19-24. https://doi.org/10.1080/20742835.2018.15 09928

Bandara, W. (2006). Using NVivo as a research management tool: A case narrative. Quality and Impact of Qualitative Research: QualIT 2006, Proceedings of the 3rd International Conference on Qualitative Research in IT and IT in Qualitative Research, 6-19.

Bengtsson, M. (2016). How to plan and perform a qualitative study using content analysis. NursingPlus Open, 2, 8-14. https://doi. org/10.1016/j.npls.2016.01.001

Bruns, A. (2011). Real-Time Feedback : 7, 117136.

Cottle, S. (2013). Journalists witnessing disaster: From the calculus of death to the injunction to care. Journalism Studies, 14(2), 232-248. https://doi.org/10.1080/14 61670X.2012.718556

Coward, R. (2013). Speaking Personally: The rise of subjective and confessional journalism. Palgrave Macmillan.

Cui, X., \& Liu, Y. (2017). How does online news curate linked sources? A content analysis of three online news media. Journalism, 18(7), 852-870. https://doi. org/10.1177/1464884916663621

Dahlgren, P. (2013). Online journalism and civic cosmopolitanism: Professional vs. participatory ideals. Journalism Studies, 14(2), 156-171. https://doi.org/10.1080/14 61670X.2012.718544

Fletcher, R., \& Nielsen, R. K. (2017). Paying for Online News: A comparative analysis of six countries. Digital Journalism, 5(9), 1173-1191. https://doi.org/10.1080/21670 811.2016.1246373

Guo, L., \& Zhang, Y. (2020). Information flow within and across online media platforms: an agenda-setting analysis of rumor diffusion on news websites, Weibo, and WeChat in China. Journalism Studies, 21(15), 2176-2195. https://doi.org/10.108 0/1461670X.2020.1827012

Hamilton, A. B., \& Finley, E. P. (2019). Qualitative methods in implementation research: An introduction. Psychiatry Research, 280, 112516. https://doi. org/10.1016/j.psychres.2019.112516

Houston, J. B., Pfefferbaum, B., \& Rosenholtz, C. E. (2012). Disaster news: framing and frame changing in coverage of major U.S. natural disasters, 2000-2010. Journalism and Mass Communication Quarterly, 89(4), 606-623. https://doi. org/10.1177/1077699012456022

Junaedi, F. (2011). Manajemen Penyiaran bencana. In S. Budi HH (Ed.), Komunikasi Bencana. Yogyakarta : Aspikom dan Buku Litera.

Karlsson, M., \& Sjøvaag, H. (2016). Content analysis and online news: Epistemologies of analysing the ephemeral web. Digital Journalism, 4(1), 177-192. https://doi.org /10.1080/21670811.2015.1096619

Lestari, P., Ramadhaniyanto, B., \& Wardyaningrum, D. (2018). Pemberitaan di media online untuk pengurangan risiko bencana gunung Sinabung. Jurnal Kajian Komunikasi, 6(1), 106-120. https://doi. org/10.24198/jkk.v6i1.15168

Matheson, D. (2004). Weblogs and the epistemology of the news: Some trends in online journalism. New Media and Society, 6(4), 443-468. https://doi. 
org/10.1177/146144804044329

Nazaruddin, M. (2015). Jurnalisme bencana Di Indonesia, Setelah Sepuluh Tahun. Jurnal Komunikasi, 10(1), 79-88. https://doi. org/10.20885/komunikasi.vol10.iss1.art8

Neuendorf, K. A. (2017). The content analysis guidebook. In SAGE Publication (Secomd Edi). https://doi.org/10.1007/s11589-9980087-6

Nugroho, Y., Putri, D. A., \& Laksmi, S. (2012). Memetakan lanskap industri media kontemporer di Indonesia (Edisi Bahasa Indonesia). CIPG Dan HIVOS, 1-184.

Pantti, M., Wahl-Jorgensen, K., \& Cottle, S. (2012). Disasters and the Media. Peter Lang.

Pantti, M. (2010). The value of emotion: An examination of television journalists' notions on emotionality. European Journal of Communication, 25(2), 168-181. https:// doi.org/10.1177/0267323110363653

Papacharissi, Z. (2014). Affective publics: sentiment, technology, and politics. Oxford : Oxford University Press.

Patterson, C., Emslie, C., Mason, O., Fergie, G., \& Hilton, S. (2016). Content analysis of UK newspaper and online news representations of women's and men's "binge" drinking: A challenge for communicating evidencebased messages about single-episodic drinking? BMJ Open, 6(12), 1-10. https:// doi.org/10.1136/bmjopen-2016-013124

Putri, N. E., Hakim, N., \& Yamin, M. (2016). Ecologicall footprint and biocapacity analysis for flooding prevention in South Sumatera. Jurnal Mimbar, 32(1), 58-64.

Richards, B. (2007). Emotional governance: politics, media and terror. London : Palgrave Macmillan.

Sanusi, H. (2018). Jurnalisme dan bencana (refleksi peran jurnalis dalam liputan bencana gempa, Tsunami dan Likuifaksi Palu-Donggala). Jurnal Jurnalisa, 4(2), 211-225. https://doi.org/10.24252/ jurnalisa.v4i2.6895

Stone, R., \& Socia, K. M. (2019). Boy with toy or black male with gun: an analysis of online news articles covering the shooting of tamir rice. RaceandJustice, 9(3),330-358.https:// doi.org/10.1177/2153368716689594

Sukmono, F. G., \& Junedi, F. (2018). Menggagas jurnalisme optimis dalam pemberitaan tentang bencana. Jurnal ILMU KOMUNIKASI, 15(1), 107-119. https://doi. org/10.24002/jik.v15i1.882

Sundari, S., \& Salamah, S. (2019). Gatewatching behind the beating case of ratna sarumpaet in tribunnews.com and Detik.com. Komunikator, 11(1), 28-37. https://doi. org $/ 10.18196 / \mathrm{jkm} .111017$

Wahl-Jorgensen, K. (2014). Changing technologies, changing paradigms of journalistic practice: Emotionality, authenticity and the challenge to objectivity. In \& M. S. C. Zimmerman (Ed.), Technologies, Media and Journalism (pp. 264-283). London : Yale University Press.

Woolf, N. H., \& Silver, C. (2018). Qualitative analysis using nvivo, the five level qda method. In Routledge (pp. 1-1235). Britania Raya : Routledge.

Zhang, X., \& Luther, C. A. (2020). Transnational news media coverage of distant suffering in the Syrian civil war: An analysis of CNN, Al-Jazeera English and Sputnik online news. Media, War and Conflict, 13(4), 399-424. https://doi. org/10.1177/1750635219846029 